\title{
Smart learning environments: a basic research towards the definition of a practical model
}

\author{
Pedro Antonio García-Tudela* (D), Paz Prendes-Espinosa(iD and Isabel María Solano-Fernández(D)
}

\author{
* Correspondence: pedroantonio. \\ garcia4@um.es \\ University of Murcia, Campus \\ Universitario Street, No. 12, PC, \\ 30100 Murcia, Spain
}

\begin{abstract}
This paper is basic research focused on the analysis of scientific advances related to Smart Learning Environments (SLE). Our main objective is to single out the common aspects to propose a new definition which will constitute the starting point to design an innovative model which we can apply to the analysis of real cases and good practices. For this, we have proposed a qualitative methodology that has been implemented in two phases: on the one hand, a documentary analysis of the existing definitions for SLE using the NVIVO program (frequency of words, coding and cross-references) and, on the other, an expert judgement by means of the Delphi method in order to validate the proposed model. The main results are reflected in the coalescence of a new definition of SLE and the proposal of the model entitled SLE-5. With the present research, we have been able to provide a model, defined in five dimensions and other key elements in SLE such as ergonomics and learning analytics, which transcends the technological-pedagogical gap of the SLE and offers a framework for the design and analysis of didactic proposals based on this model.

Keywords: Educational technology, Smart learning environment, Smart education, Smart technology, Ergonomics, Basic research
\end{abstract}

\section{Introduction}

This paper is focused on Smart Learning Environments (SLE in advance) as a new educational approach to understand the impact and potential uses of technologies in classrooms. In this article we intend to clarify the theoretical approach to SLE and to design an innovative model around it. In this first section, we justify the interest of this concept because the impact of digital technologies in our world in general, and in our education in particular. Next we focus on the differences between SLE and other concepts related to technology enhanced learning. This theoretical framework is the base to review the different definitions of SLE using a qualitative research method, revision which will be the ground to build our definition of SLE. We understand SLE from an inclusive view in the sense of adaptation and personalization of the physical and virtual scenarios according to the teaching and learning needs in every specific context.

(c) The Author(s). 2021 Open Access This article is licensed under a Creative Commons Attribution 4.0 International License, which permits use, sharing, adaptation, distribution and reproduction in any medium or format, as long as you give appropriate credit to the original author(s) and the source, provide a link to the Creative Commons licence, and indicate if changes were made. The images or other third party material in this article are included in the article's Creative Commons licence, unless indicated otherwise in a credit line to the material. If material is not included in the article's Creative Commons licence and your intended use is not permitted by statutory regulation or exceeds the permitted use, you will need to obtain permission directly from the copyright holder. To view a copy of this licence, visit http://creativecommons.org/licenses/by/4.0/. 
Once we built this definition, we will design an innovative model of SLE (named SLE-5), useful to promote further research, both theoretical and empirical studies to check how teachers design the educational environment to promote student's learning using SLE.

Technology is causing a reconceptualization of smart transport, energy, health, security, among other dimensions that define a city (Albino, Berardi, \& Dangelico, 2015). Mainly, this smart view seeks to improve the living standards of any citizen through the integration and daily use of Information and Communication Technologies (ICT), which are embedded in a system led by artificial intelligence, the Internet of Things (IoT), cyber-physical environments, among other concepts related to urban digitization and connectivity (Roblek \& Meško, 2020).

Generally, in an educational context, the adjective smart or intelligent appears linked to a physical space, for example "smart universities", or "smart classrooms", or also, to other concepts related to the educational discipline, such as "smart pedagogy", "smart learning", "smart teachers" and others (Heinemann \& Uskov, 2018). Despite this conceptual plurality around smart learning or smart education, the fact of considering a class smart should not be confused with the provision of smart technology (hardware and software) to the physical classroom, which is known as "technology-enriched classrooms", "enriching classrooms with technology" or similar concepts (Kurt, 2014; Wakil, Qaisar, \& Mohammed, 2017).

Classrooms enriched with technologies usually present different educational possibilities, although also some risks, and in this article one of them should be highlighted, since it is a shared risk between any type of Technology Enriched Learning (TEL). This risk consists in assuming that educational innovation is understood only as the presence of technologies and the latest computer advances (Prendes, 2018). However, to adapt the teaching-learning process to any TEL proposal implies taking into account the models to integrate with ICT in the curricula and, moreover, considering all the educational competencies, plus the technological skills and the knowledge about the contents, such as TPACK (Koehler \& Mishra, 2009) or recommendations that have been formulated based on them (Harris \& Hofer, 2009). Educational technology also plays a crucial role in creating these new scenarios enriched by technologies, since the digitization of content and teaching activity enables the creation of new virtual environments from which to develop the teaching and learning process (Castañeda, Gutiérrez, Prendes, \& Sánchez, 2017; Salinas, 2012).

Some authors have shown that SLE do not present a clear and unified definition (Kim, Cho, \& Lee, 2013; Zhu, Sun, \& Riezebos, 2016), since many of those are usually based on generic/general principles, such as the five pointed out by the Korean Ministry of Education, Science and Technology: self-directed, motivated, adaptive, resourceenriched and technology-integrated (Huh \& Lee, 2019). From an exclusively educational perspective, it is usually believed that SLE are aimed at breaking spatial-temporal barriers and providing a more personalized education. Therefore, technology acquires such importance in SLE because it contributes to adapt and personalize the educational experience (Gambo \& Shakir, 2019). Fully related to this objective, the concept of ergonomics arises, which, according to Bdiwi, de Runz, Faiz, and Cherif (2019) is one of the three requirements to develop an SLE. In García-Tudela, Prendes-Espinosa, and Solano-Fernández (2020) an approach to the state of the art of ergonomics and SLE is 
formulated; it concludes that it is an optimal concept to define one of the keys to these emerging environments, that is, their inclusive nature. In other words, ergonomics supposes the inclusive view of the SLE in the sense of adaptation and personalization of the physical and virtual scenarios according to the context and the teaching and learning needs.

In general terms, according to different authors, SLE have been defined as cyberphysical systems (Lei, Wan, \& Man, 2013), "phygital" learning spaces (Giovannella, 2014), among other concepts that show the mixed nature (virtual and face-to-face) that these environments must possess. However, it would not be necessary to use the SLE concept if its practice was based solely on combining face-to-face learning with elearning -asynchronous and/or synchronous- (Kim, Bonk, \& Oh, 2008). To clarify SLE, it is interesting to compare SLE with other concepts which have become merged or confused among them, they are: blended learning (b-learning), mobile learning (mlearning) and ubiquitous learning (u-learning). The comparisons between all these concepts will lead us to clarify the concept of SLE itself.

\section{Differences between SLE and B-Learning}

B-learning has also been defined as any face-to-face educational experience in which a virtual environment is incorporated (Salinas, De Benito, Pérez, \& Gisbert, 2018). Besides, not only does it affect the resources utilized but also the methodologies (Bartolomé-Pina, García-Ruiz, \& Aguaded, 2018). If the main properties of B-Learning are considered, reductionist approaches to the SLE concept should be discarded. Mainly, because it is promoting one of the risks associated with the diffusion/spread of innovation pointed out by Govender and Dhurup (2014), that is, its complexity. In other words, if SLE are solely defined as the use of technologies in face-to-face and virtual/online environments, that would lead to an inconsistent definition, proper/inherent to B-Learning and, therefore, the progress of SLE would be impaired.

More specifically, and regarding B-Learning this is said to be classified into various types or models, according to the reference authors (Graham, 2006; Graham, Henrie, \& Gibbons, 2013; Salinas et al., 2018). Regardless of the classification taken into account and the B-Learning option chosen, all of them are based on two alternatives: the parallel use of face-to-face and virtuality (for example, the combination of face-to-face practices with activities through a virtual classroom), or the differentiated use of face-toface and virtuality (initial and final part of a course virtually, and the rest, face-to-face).

In view of the information exposed above, it must be stated that an SLE would not be defined under a face-to-face teaching modality, or virtual, but rather as a combination of both environments. Specifically, a parallel or hybrid use of them.

\section{Differences between SLE and M-Learning}

It must be clarified that M-Learning is usually defined as a progress of E-Learning, although this makes it difficult to characterize M-Learning itself (Winters, 2007). Despite the fact that M-Learning is usually considered an evolution of E-Learning, currently it could also be considered as a possibility of B-Learning, that is, a learning that combines face-to-face education with a M-learning initiative (Katoningish, Wardhani, \& Fauziah, \& Astuti, W., 2020). 
Specifically, in M-Learning, this is mainly based on teaching and learning using mobile devices such as tablets, smartphones, notebook devices, etc., through which the same benefits of E-Learning are favored, plus others such as: a more flexible communication, access to information anywhere and anytime, etc. (Gikas \& Grant, 2013; Lazar \& Milena, 2013).

The main relationship that M-Learning has with SLE is that both are based on the use of smart devices (Coccoli, Guercio, Maresca, \& Stanganelli, 2014), since currently, M-Learning is not characterized by the use of PDAs or mobile phones (Whalley, France, Park, Mauchline, \& Welsh, 2020). However, the concept of SLE should not be justified solely in the use of smart devices (Kim et al., 2013), since if so, it would be more appropriate to use the concept of M-Learning, or even, U-Learning.

\section{Differences between SLE and U-learning}

Similarly to the previous case, U-Learning is also considered a step beyond MLearning, and consequently, E-Learning (Ferri, D’Andrea, Grifoni, \& Guzzo, 2018). In general terms, U-Learning has been defined as the teaching-learning process that is based on ubiquitous computing through handheld terminals. So that something is learned at the right time and place in the right way (Sarrab, 2019).

Many definitions of U-Learning and M-Learning overlap, including some didactic experiences that have been put into practice. Namely, Hwang and Tsai (2011) point out that it is because despite their different origins, they both share the same idea. For this reason, in this work we highlight that U-Learning differs from MLearning in a smart property, specifically, in its system awareness, which, according to some authors, is formed by three vertices: context-awareness, learner-awareness and location-awareness (Cárdenas-Robledo \& Peña-Ayala, 2018) and according to others, this smart property of U-Learning is synthesized in context awareness (Sarrab, 2019). In a concise way, this smart property is defined as the ability to constantly obtain information about the student's environment and, thus, offer a personalized learning experience (Virtanen, Haavisto, Liikanen, \& Kääriäinen, 2018).

The close relationship that U-Learning has with SLE has implied that, in certain works, the concept of "Smart Ubiquitous Learning Environments" is featured (Montebello, 2017). However, the fusion of both concepts could bring about the statement already alluded to by Govender and Dhurup (2014), that is, a conceptual proliferation that hinders the theoretical conception of SLE.

In order to establish a differentiation between the aforementioned concepts, ubiquity will be considered as a key component of the SLE, as it has been exposed in other papers (Khlaif \& Farid, 2018). In other words, the idea of appropriating the characteristics of SLE for U-Learning and vice versa is rejected. The ubiquity within the SLE is seen as the characteristic that guarantees the student's access to content, activities, explanations, suggestions and other teaching materials at any time and place through different technologies. Likewise, ubiquity defines a large part of the adaptability of SLE, since due to context-awareness, a personalized learning experience is offered to students (Kinshuk, Chen, Cheng, \& Chew, 2016; Siripongdee, Pimdee, \& Tuntiwongwanich, 2020). 


\section{Learning models based on technologies to learn}

With the aim of facilitating the understanding of this theoretical exposition around different concepts related to educational use of smart technology, the following conceptual map has been generated considering the environment, presence of technology and other critical factors (Fig. 1).

We understand the different educational contexts as a continuum where we can develop face-to-face education using technologies, or we can design blended-learning methodologies using digital technologies as complementary tools in different levels and grades, or finally we can support education on technologies, understanding digital tools as the main instrument to develop the communication and information processes. Finally, it is relevant to consider the idea that Smart Learning is conceptualized in some works as a new educational paradigm (Semenova, Svyatkina, Pismak, \& Polzhaeva, 2017; Tikhomirov, Dneprovskaya, \& Yankovskaya, 2015), so it is relevant to design a SLE model to specify such paradigm. It is intended that this SLE model could be adaptable to any educational level (primary, secondary, university, vocational training), since SLE are sometimes conceived as an exclusive opportunity for higher education (Berdnikova, Mikhalenok, Pavlova, Gortcevskaia, \& Krivtsov, 2020; Gambo \& Shakir, 2019). We introduce this innovative model in the next sections.

\section{Problem and objectives}

Our starting point is the idea that SLE is an innovative concept, with different definitions and approaches that hinder practical analysis of these type of teaching and learning contexts. Our research problem is: what is an SLE? In other words, is it possible to find a general definition to be accepted by the scientific community?

Trying to solve these research questions, our general objective is to find a SLE model which we can apply to design didactic proposals. Next, we define its specific objectives:

- Analyse the definitions and models proposed about SLE trying to find the common elements and the differences among them.

- Design an SLE model transferable to any educational level.

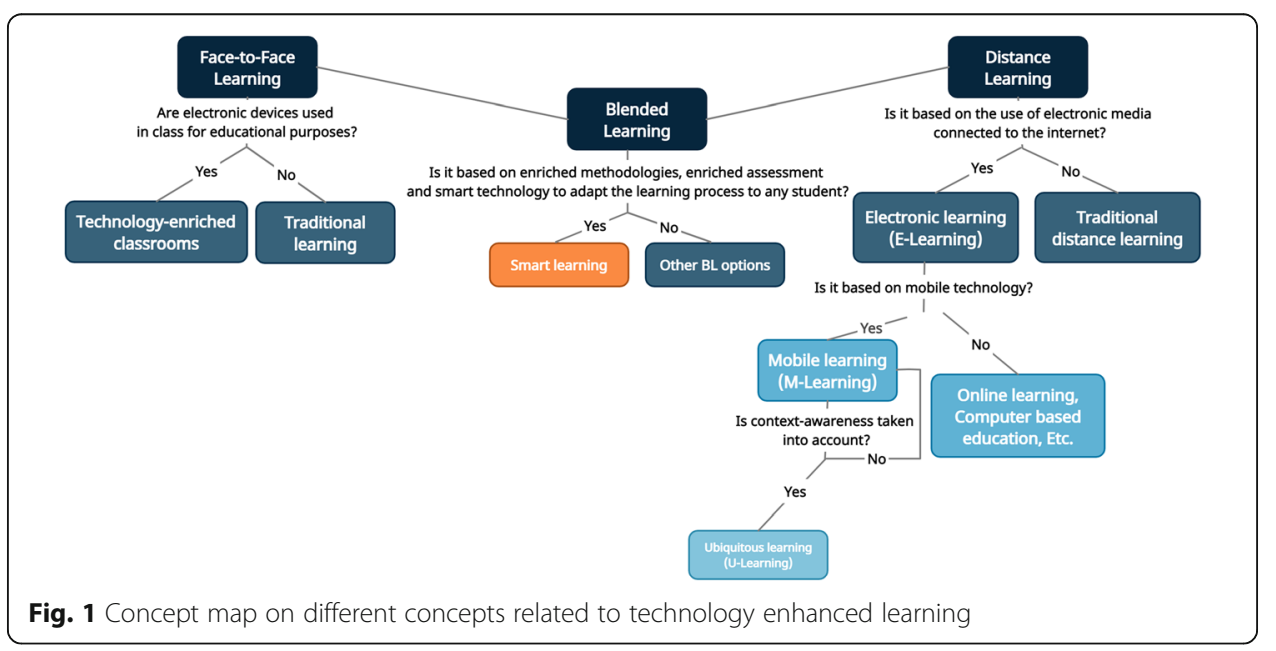




\section{Method}

It is basic research of a deductive type, using a qualitative method based on documentary analysis and expert judgement techniques. Part of the methodology is known as grounded theory, whose objective is to theorize and generate concepts and hypotheses on generally novel research areas. For this, it is essential to rely on other works that have a close relationship with the object of study. In this way, data are analyzed to create categories, study their relationship and finally reach theoretical saturation, that is, until the latest data collected does not offer new theoretical elements (Sabariego, Massot, \& Dorio, 2004).

\section{Phases}

This research has been divided into three phases. One first phase, we have carried out a search of SLE definitions, based on which a new definition has been suggested. In a second phase, we made a content analysis of different models or frameworks about SLE, since they can be named in both ways (Yusufu \& Nathan, 2020). Once we have the proposal of a new model derived from the analytical review of literature, it is considered appropriate to apply a validation technique in the third phase: an expert judgement, a frequently utilized technique in qualitative and exploratory studies which takes into consideration a sample of experts in a given topic (Hernández, Fernández, \& Baptista, 1991).

\section{Process}

Our starting point has been an exhaustive review of bibliography from an analytical approach, we have searched for them in the most relevant databases of scientific journals (WOS and Scopus) and the most used academic search tool (Google Scholar), selecting the last 10 years period. This analytical review has the objective of defining a concept of SLE derived from the definitions of other authors. Mainly, the collection and analysis of concepts related to SLE stems from the elements included in every definition and limitations of each one. The chosen SLE definitions have been analyzed with the qualitative data analysis program NVIVO. Specifically, we start by checking the frequency of words through a word cloud in order to create the appropriate codes. Next, these codes are associated with the different definitions analyzed. Finally, a new definition of SLE is put forward; one which encompasses all of the codes.

In the second phase, we analysed models and/or frameworks. After the application of boolean searches ("framework" OR "model" AND "smart education" OR "smart learning" OR "smart learning environments") in the same databases (WOS, Scopus and Google Scholar) over the last 6 years (2014-2020), we did a list of dimensions that are included in all the models. Dimensions, components, categories or requirements presented by some SLE models or frameworks have been discussed. With this theoretical approach to SLE, we have designed our own model (SLE-5) with interesting implications for further research.

Finally, we used the experts' judgement. For doing so, the Delphi method, which is based on consulting a group of experts on a topic (Reguant-Álvarez \& TorradoFonseca, 2016) has been employed. This technique is valued as optimal for the objective pursued (Luna-Gijón \& Porras-Hernández, 2014; Yeh, Hsu, Wu, Hwang, \& Lin, 
2013). For the selection of experts, two criteria were applied: university professors with more than 10 years' experience and being well versed in Educational Technology. Although we sent the grid to seven experts, only six of them answered. The grid was designed with a four-level answer scale to measure the appropriateness, ambiguity and importance of the dimensions of SLE- 5 and other key elements of the model. Likewise, next to each dimension, a qualitative justification of their answers was requested.

\section{Data analysis}

The definitions of SLE selected during the first phase have been analyzed with data analysis tool NVIVO. Specifically, we start by checking the frequency of words through a word cloud in order to create the appropriate codes. Next, these codes are associated with the different definitions analyzed. Finally, a new definition of SLE is put forward; one which encompasses all of the codes. For the second phase, a method of comparative analysis of dimensions has been employed. And lastly, in the third phase a validation of content based on the answers given by the experts has been performed, carrying out a statistical-descriptive analysis, derived from the average scoring of experts, along with a qualitative content analysis of the observations and assessment provided by the experts.

\section{Results}

\section{Analysis of definitions of SLE}

In the first phase, we have identified the most widespread definitions (most cited ones) about SLE in the last 10 years. We will show the definitions with a chronological order. The first definition shows smart technology as the epicentre of SLE, leaving pedagogy subordinate to these digital tools. It is not justified what a smart environment is, since it only exposes that intelligent technologies should be used to provide personalized learning services (Zhu \& He, 2012 cited by Zhu, Yu, \& Riezebos, 2016, p. 6).

"The essence of smart education is to create intelligent environments by using smart technologies, so that smart pedagogies can be facilitated as to provide personalized learning services and empower learners, and thus talents of wisdom who have better value orientation, higher thinking quality, and stronger conduct ability could be fostered".

Other authors (Coccoli et al., 2014, p. 1004) explain SLE as "Smart environment supported by smart technologies, making use of smart tools and smart devices". The accent of this definition lies in the technological devices, which diminishes all the importance that the pedagogical dimension (methodologies and evaluation) has in the development of the SLE. Furthermore, it is incomplete to consider that SLE should only contemplate the use of smart digital resources.

Hwang (2014, p. 2) explains that "A smart learning environment not only enables learners to access digital resources and interact with learning systems in any place and at any time, but also actively provides the necessary learning guidance, hints, supportive tools or learning suggestions ... in the right place, ... right time and ... right form". Although the intention of smart learning is clearly appreciated, it is difficult to implement 
a proposal based on this definition due to the disruptive nature it entails, because educational centers would need a very specific technology.

Koper (2014, p.1) defines SLE as: "Physical environments that are enriched with digital, context-aware and adaptive devices, to promote better and faster learning." In some cases, the potential of context-awareness is valued as an opportunity in informal education (Hasanov \& Laine, 2017). Moreover, technology is the only key in this definition.

Spector (2014, p.2) understands that a SLE includes "features to promote engagement, effectiveness and efficiency. Such features might include support for collaboration ... struggling learners ... motivation. In addition, a learning environment that automatically makes appropriate adjustment." Despite its focus on attention to diversity, which is essential to the concept analysed, this definition could delve into what a SLE is. So, it could be interpreted that this is a classroom enriched with adaptive technology.

For Li et al. (2015, p.2), SLE "always represents the technology-rich classroom, iclassroom or future classroom and it is linked to emerging technology like wireless communication technology, context awareness technology, massive data mining and analysis, and smart interactive technology, smart classroom." This definition has numerous concepts without a specific connection, that is, without establishing a connection between them and how they favour the development of an SLE.

Another definition is from Tikhomirov et al. (2015, p. 54): "Using ICT in the educational process initially involved in the paradigm of smart education because the creation of flexible and well-adapted educational trajectories is possible only by applying automated intelligent big data processing and internet technologies of distance education." They consider SLE as an exclusive possibility of distance education, which would make it impossible to develop smart learning at levels in which presence is mandatory.

Kinshuk et al. (2016, p.4) understand that SLE "engage and integrate formal and informal learning in order to create autonomous adaptive learning environments for supporting individual learners with real-time and seamless learning experiences in ubiquitous settings." Expanding the possibilities of an SLE for informal and formal education in the same definition could be a complex fact, since it is necessary to go into depth theoretically and practically in each of the two alternatives to specify its dimensions, models, risks, etc. Furthermore, limiting SLE to real-time experiences could eclipse the teaching and learning possibilities that asynchronous technology can deliver. Finally, it is necessary to highlight how inappropriate autonomous learning can be in early educational levels.

In the last selected definition by Yusufu and Nathan (2020), the expression "anywhere at any time" (p.3) should not be interpreted -or at least for the moment and in the first educational levels- as the free and autonomous management of learning.

"A student-centric intelligent learning environment enriched with digital learning resources to provide smart pedagogies that support smart learners' personalised learning experiences anywhere at any time using smart portable devices and linked across educational institutions or training workforce through the advancement and superiority of smart and wireless technologies." (p.3). 
The first step to creating a new concept of SLE, together with taking into account each of the conceptual necessities detailed in the paragraphs above, is to check the frequency of words in the definitions by means of a word cloud (Fig. 2). The most used words are: technology, learning, learners, smart, support, environment and education.

Secondly, bearing in mind the frequency of words and delving into each of the definitions, a total of 10 codes has been created in order to codify the 9 definitions. The results are exposed in the shape of a hierarchical framework so as to ascertain the total of codes devised according to their presence in the definitions (Fig. 3).

As a final step before conceiving our own definition, it is necessary to analyze the presence of codes according to the referenced authors in each definition. For doing so, a coding matrix has been utilized. As it can be seen in Table 1, the works with more codes associated with them are (Zhu \& He 2012, p. 6 cited in $\mathrm{Zhu}, \mathrm{Yu}$, \& Riezebos, 2016, p.6) and Yusufu and Nathan (2020), with 5 codes each. On the other hand, the work with fewest codes is Coccoli et al. (2014), as it defines SLE focusing solely on the code "(smart) technology".

Arriving at a new concept of SLE based on this analysis, the definition proposed in this work offers a realistic perspective, with potential application to any formal educational context that has the necessary support. It is necessary to present this preamble, since many definitions are based on customization, adaptability, flexibility, among other principles without offering a model or certain guidelines on how to put the SLE into practice. Likewise, it is necessary to emphasize that this definition is oriented to formal education because in some works it has been justified that adaptability linked to context awareness through RFID / NFC or other sensors -idiosyncratic of ubiquitous learning, is very focused on informal learning in contexts such as museums, science centers, parks, etc. (Hasanov \& Laine, 2017).

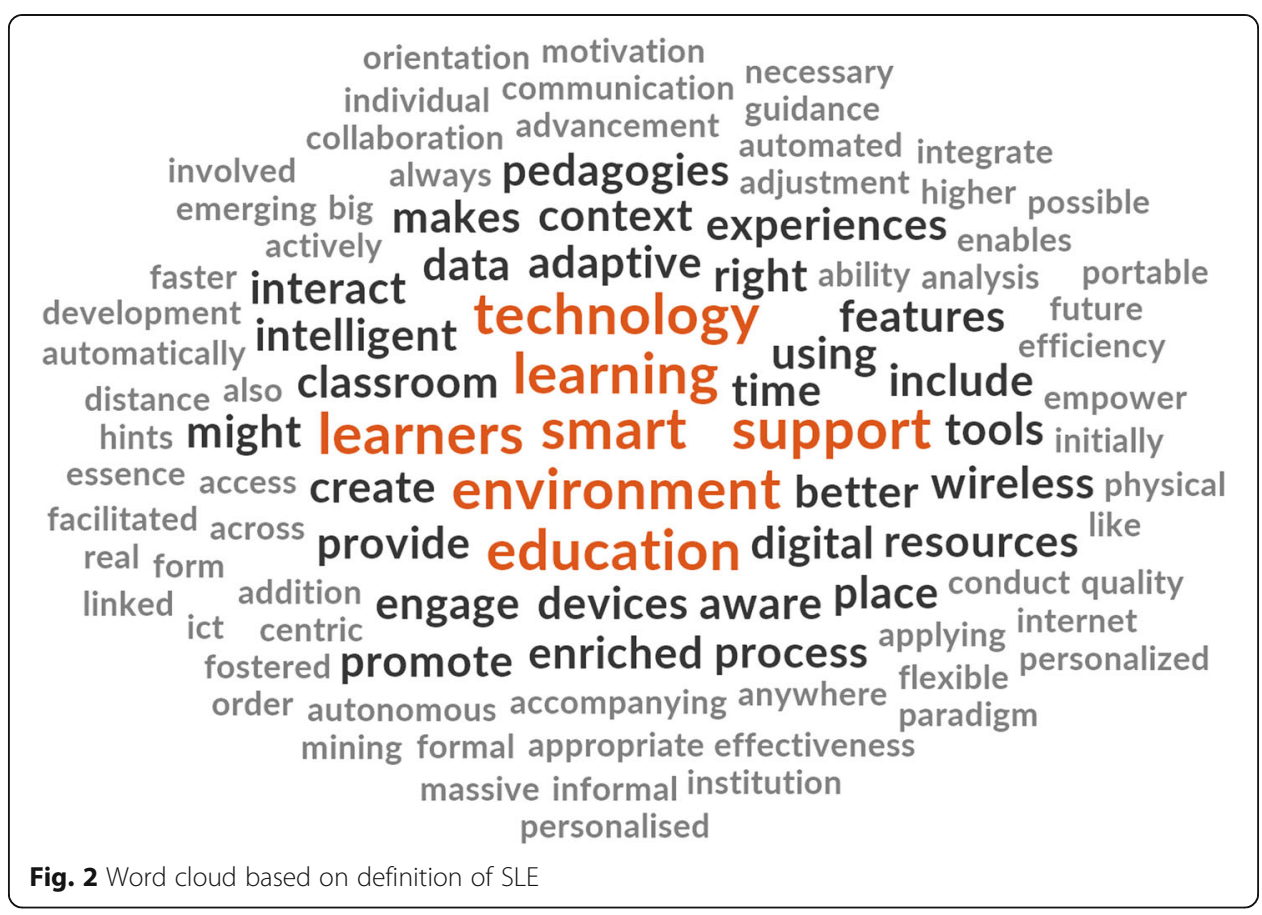




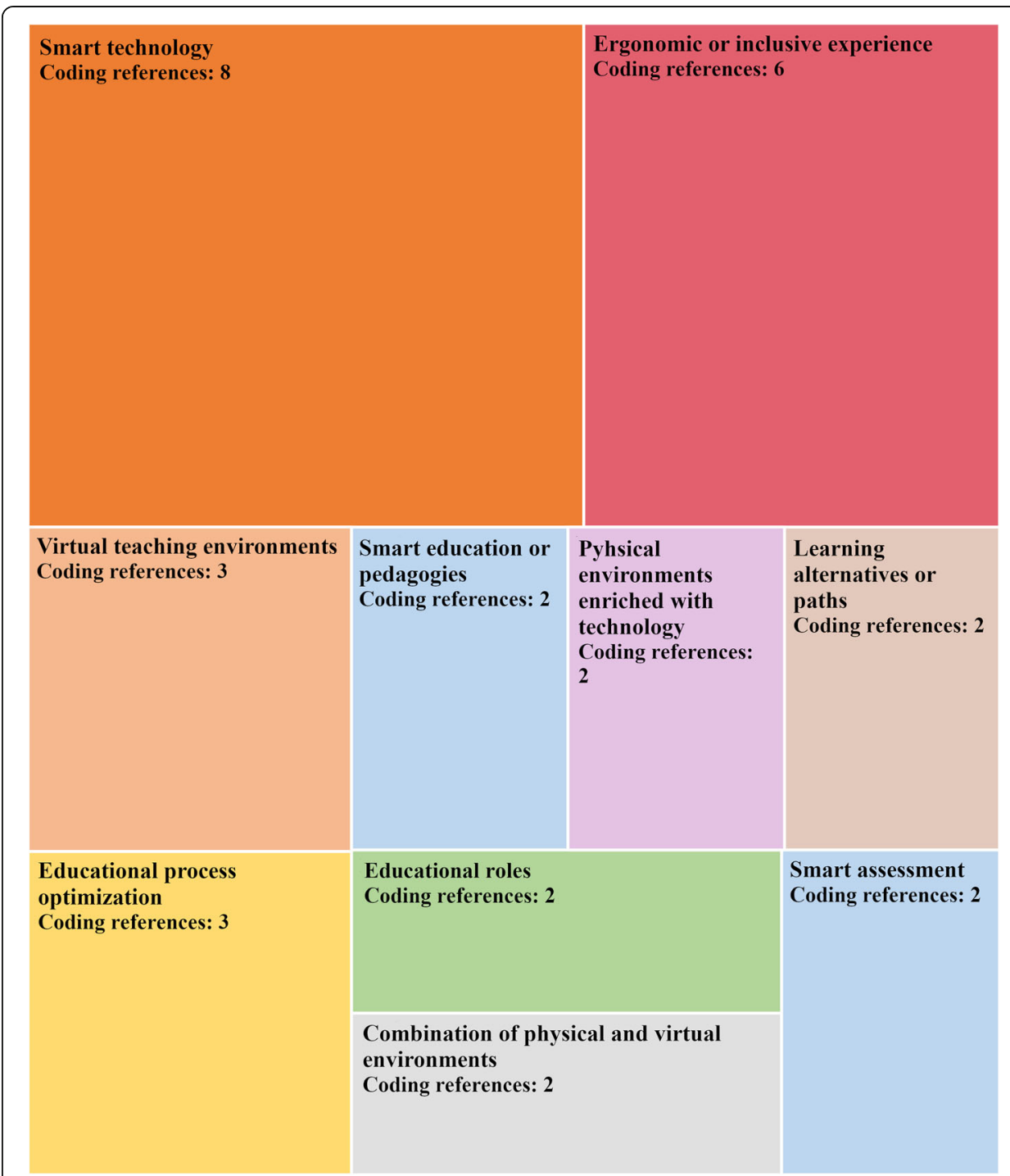

Fig. 3 Hierarchy chart about created codes

Unlike other cases, our definition is not directed at only higher education, since it makes no sense to frame the SLE as a part of smart cities and not to contemplate the progress towards smart education at levels such as primary or secondary. This reason justifies that although smart learning is located within the B-Learning, absolute freedom to learn when and where you want cannot be guaranteed, since face-to-face attendance is mandatory in the educational system. However, in vocational training programs, university degrees, master's studies, etc., a more flexible redefinition of the proposal presented here could be contemplated.

In conclusion, we proposed a new definition of SLE based on this previous analysis. To show the relation between the definition and the analysis we use the Fig. 4, where it is possible to see what elements are on the previous definitions and the frequency. It can be observed that there is a greater prominence of those terms related to educational inclusion and the combination of virtual and physical environments. Our new definition about SLE is: 
Table 1 Coding query matrix about definitions according to codes

\begin{tabular}{|c|c|c|c|c|c|c|c|c|c|c|}
\hline Reference & 1 & 2 & 3 & 4 & 5 & 6 & 7 & 8 & 9 & 10 \\
\hline Coccoli et al. (2014) & No & Yes & No & No & No & No & No & No & No & No \\
\hline Hwang (2014) & Yes & Yes & Yes & No & No & No & No & No & No & Yes \\
\hline Kinshuk et al. (2016) & No & No & No & No & No & Sí & No & No & No & Yes \\
\hline Koper (2014) & No & Yes & No & Yes & No & Yes & No & Yes & No & No \\
\hline Li et al. (2015) & Yes & Yes & No & No & No & No & No & Yes & No & No \\
\hline Spector (2014) & No & Yes & No & Yes & No & Yes & No & No & No & No \\
\hline Tikhomirov et al. (2015) & No & Yes & No & No & No & Yes & Yes & No & No & Yes \\
\hline Yusufu \& Nathan (2020) & No & Yes & Yes & No & Yes & Yes & Yes & No & Yes & No \\
\hline Zhu \& He (2012) in Zhu et al. (2016b) & No & Yes & No & Yes & Yes & Yes & No & No & Yes & No \\
\hline
\end{tabular}

1. Smart assessment; 2 . Smart technology; 3 . Combination of physical and virtual environments; 4 . Educational process optimization; 5. Educational roles; 6 . Ergonomic and inclusive experience; 7. Learning alternatives or paths; 8 . Physical environments enriched with technology; 9 . Smart education or pedagogies; 10 . Virtual teaching environments

Physical environments enriched with technology and augmented with virtual education environments so as to optimize the training activity. By means of enriched methodologies and strategies and enriched assessment the cohesion between both environments (face-to-face and virtual) is promoted, thus creating a context enriched with new learning possibilities for each of the students. Likewise, smart technology brings together the whole community and models experiences built upon the ergonomics of the SLE itself.

\section{Models and dimensions of SLE}

After searching in the most important data bases of literature, Table 2 shows the results according to the dimensions of each analyzed model.

The model of Zhu, Sun, and Riezebos (2016) is complete in the sense of contemplating many of the concepts related to our SLE model. However, "learner presence" is a dimension only limited to students. A dimension related to the curriculum is not contemplated, nor is it the educational legislative dimension. The absence of learning analytics as an indicator of this model makes it less valuable. The concept of ubiquitous as it is presented ("study whenever and wherever they want "p.61) makes it difficult to apply in an ordinary educational context at the initial educational levels. The category "efficient technology user" could emphasize the distortion of educational technology, since it must be understood as a medium, not an end.

$\mathrm{Zhu}, \mathrm{Yu}$, and Riezebos (2016) design a model to explain that SLEs are the application of smart education and that smart learners are efficiently trained through smart pedagogies. On the other hand, it is not an optimal model for a teacher who wants to 


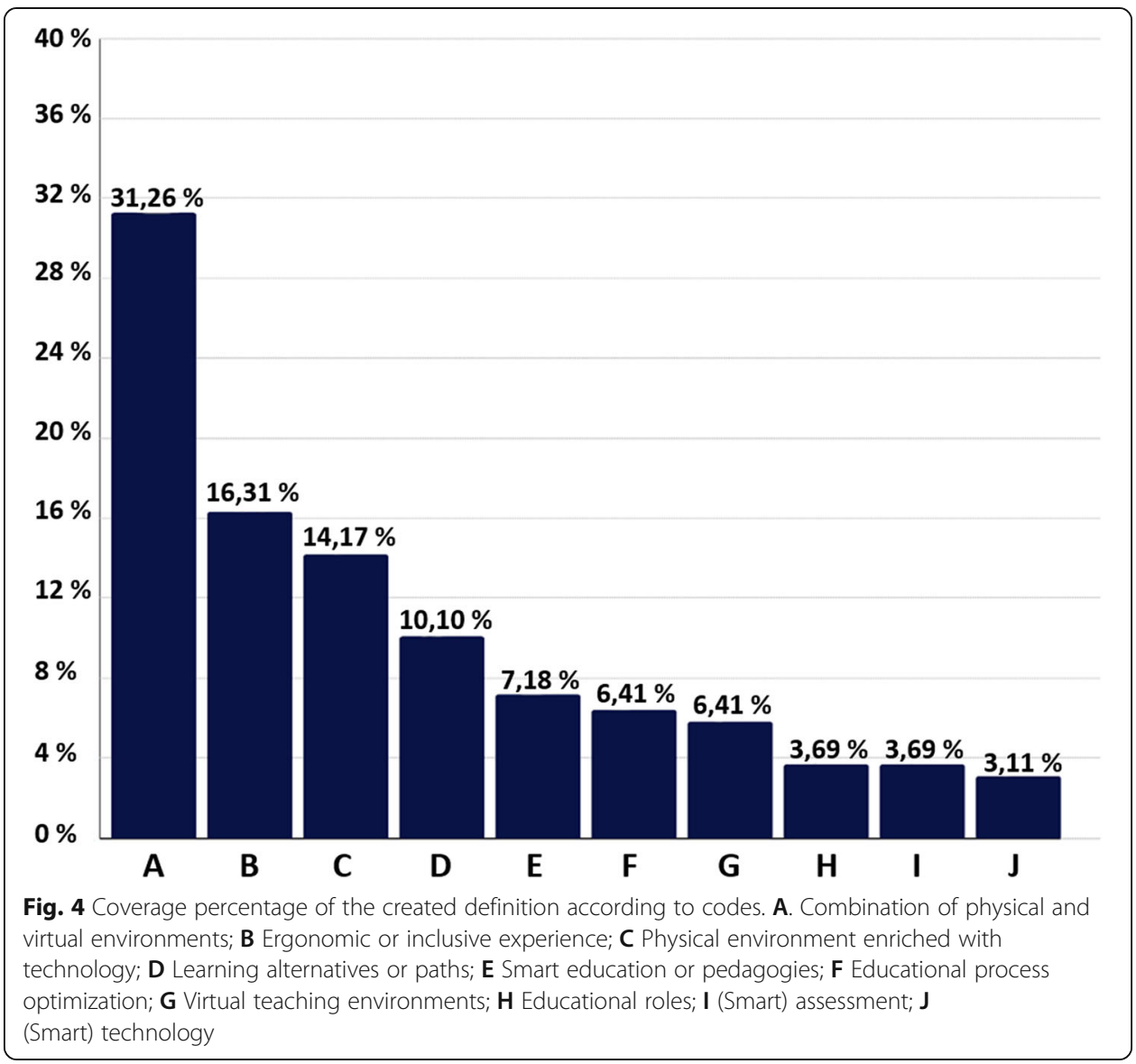

implement a smart experience, or an approach to it, since the diagram is very simple and when delving into the different dimensions, technical and complex concepts are exposed to start implementing some first SLE proposals, such as: "whole record", "mass-based generative learning", "swarm computing", etc.

The model of Laxmikant (2017) is the furthest case from educational reality and that presents the most difficulties when interpreting its components, since no clear definitions are exposed either. Although the author recognizes that one of the main contributions of the work has been an innovative approach to SLE, it is very difficult to relate these contributions to the rest of the cases -which are more similar to each other.

The diagram designed by Liu et al. (2017) is the most complex, mainly due to its amount of information. The level of "learning experience", as in other cases, implies difficulties to apply them in the first educational levels. The third level, "core elements of learning scenarios" contains numerous categories that without a clear guide it is difficult to design a proposal based on an SLE according to this model. The fourth level "logical laws for teaching and learning" also involves a complex interpretation, since it is the most abstract level. It is the only model that has included a category of "learning content", which is fundamental, since it must be a pillar of any proposal, although other elements of the educational curriculum could also be considered.

Taking into account the smart learning environments modules by Hwang (2014), it should be noted that the idea of blended is not emphasized, although it highlights the importance of offering an adaptive experience. Despite being the model with the most 
Table 2 SLE models or frameworks (chronologically ordered)

\begin{tabular}{|c|c|}
\hline Reference & Model dimensions \\
\hline \multirow[t]{7}{*}{ Hwang (2014) } & - Learning status detecting module. \\
\hline & - Learning performance evaluation module. \\
\hline & - Adaptive learning task module. \\
\hline & - Adaptive learning content module. \\
\hline & - Personal learning support module. \\
\hline & - Set of databases for keeping the learner profiles, learning materials, etc. \\
\hline & $\begin{array}{l}\text { - Inference engine and a knowledge base for determining the "value" of the } \\
\text { candidate learning tasks, strategies and tools. }\end{array}$ \\
\hline \multirow[t]{3}{*}{$\begin{array}{l}\text { Zhu, Sun, and Riezebos } \\
\text { (2016) }\end{array}$} & $\begin{array}{l}\text { - Teaching presence (instructional design, facilitation and direct instruction and } \\
\text { technological support). }\end{array}$ \\
\hline & - Technological presence (connective, ubiquitous access and personalized). \\
\hline & $\begin{array}{l}\text { - Learner presence (autonomous learner, collaborative learner and efficient } \\
\text { technology user). }\end{array}$ \\
\hline \multirow[t]{4}{*}{ Zhu, Yu, and Riezebos (2016) } & - Smart environments. \\
\hline & - Smart pedagogy (contemplates the inclusive educational view). \\
\hline & - Smart learners. \\
\hline & It contemplates a 4-level architecture of intelligent pedagogies. \\
\hline \multirow[t]{3}{*}{ Laxmikant (2017) } & - Connectivity (loT). \\
\hline & - Business model. \\
\hline & - Killer applications (applications for data management). \\
\hline \multirow{4}{*}{$\begin{array}{l}\text { Liu, Huang, and Wosinski } \\
(2017)\end{array}$} & - Learning experience (any place, way, time and pace). \\
\hline & - Supporting technologies (advice and supportive technology). \\
\hline & $\begin{array}{l}\text { - Core elements of learning scenarios (learning tasks, learning methods, learning } \\
\text { goals, learning space, learning community, etc.) }\end{array}$ \\
\hline & - Logical laws for teaching and learning. \\
\hline \multirow{5}{*}{$\begin{array}{l}\text { Freigang, Schlenker, and } \\
\text { Köhler (2018) }\end{array}$} & - Participatory corporate culture. \\
\hline & - User centricity. \\
\hline & - Didactical variety. \\
\hline & - Hybrid learning space. \\
\hline & - Hybrid learning assistance. \\
\hline \multirow[t]{3}{*}{$\begin{array}{l}\text { Maulidiya, Santoso, and } \\
\text { Hasibuan (2019) }\end{array}$} & $\begin{array}{l}\text { - Smart Learning (learning activities, learning path, learning contents, learning } \\
\text { portfolio, learner behavior model). }\end{array}$ \\
\hline & $\begin{array}{l}\text { - Smart pedagogy (presentation, assessment, intervention, feedback, teaching } \\
\text { management). }\end{array}$ \\
\hline & $\begin{array}{l}\text { - Smart supporting system (smart room, e-learning system and multichannel } \\
\text { communication). }\end{array}$ \\
\hline \multirow[t]{4}{*}{ Yusufu and Nathan (2020) } & - Smart pedagogies based on learning theory. \\
\hline & - Smart learning environment (physical and virtual classrooms). \\
\hline & - Smart technologies. \\
\hline & - Smart learners (students, teachers or learning communities). \\
\hline
\end{tabular}

dimensions, there is no specific one on smart pedagogy, although there is one on learning tasks. However, this supposes a reductionist view about smart pedagogy, since it could be interpreted as that the SLE should only use the methodology known as taskbased learning.

This model offers the coalescence of different fundamental principles of the SLE, but it could cause certain difficulties to transfer to practice due to some dimensions such 
as "set of databases", closely related to learning analytics or "an inference engine and a knowledge base for determining the value". On the other hand, this author also reflects the presence of sensing devices (to control temperature, humidity, etc.), but it is not considered a priority to design a model that favors the creation of an approach to smart education.

Freigang et al. (2018) acknowledge the simplicity of the framework when it comes to putting it into practice. However, the diagram does not expose the design itinerary and the connection points are complex to interpret. Likewise, different factors such as "develop knowledge ecology", "apply privacy-by-design", "carry out comprehensive analysis of requirements", among many others, demand a greater depth to facilitate their understanding and practical transfer. It is considered a valuable contribution to complement SLE models already implemented, but not a starting point, since it would represent an educational disruption.

Maulidiya et al. (2019) present a model that shows the two environments (physical and virtual) that must be present in an SLE. However, it could generate controversy when focusing on some components of the "smart learning" and "smart pedagogy" dimensions; for example, in the case of the component "learning path", since it is considered part of "smart learning". Instead, the design of different learning alternatives must be based on educational theories that belong to the "smart pedagogy" dimension. Pedagogy includes the teaching-learning process; therefore, it is risky to create two dimensions. If so, the graphical representation should be different to appreciate the closer component relationships. On the other hand, the concepts "presentation", "intervention" and "teaching management" can pose difficulties of application if they are not studied in depth.

A possible resource in an SLE such as the "learning portfolio" is deemed a necessary component in this model. Furthermore, if it is used by teachers to evaluate, it could be considered an alternative for "assessment" from the smart pedagogy dimension, and not from the smart learning dimension. The model presents an admirable synthesis of components ordered in dimensions that facilitates the understanding of the intention of the SLE. Moreover, it reflects that students can learn anytime and anywhere according to their needs. Instead, it could be reoriented so that a teacher could design a proposal based on the model.

Yusufu and Nathan (2020) present a model to any student, who can learn anywhere and at any time while also meeting their personal needs. Creating an SLE dimension generates confusion, since the model should specify what a SLE is in order to carry out smart education. In this way, within the SLE the rest of the components that they expose would be considered, that is, "smart technology", "smart learners" and "smart pedagogies". The "smart learners" component is considered a success, since it considers the learning community in its broadest sense. However, if this component is maintained, that of "smart teachers" or "smart instructors" would have to be created, since any person involved in the educational process could have the role of educator or learner, or even evaluator, guide, etc. The description of the "smart learning environment" component can generate confusion, since it states that SLEs can be intelligent physical classrooms or virtual classrooms, when it should be a combination of both. As the model diagram and associated descriptions are presented, transfer to practice is not greatly facilitated, although the intentions of the SLEs are appropriately expressed. 


\section{Expert judgment results: Delphi method}

The original dimensions which were conceived for the new proposal of the SLE model have been altered according to the results obtained in the experts' judgement. Below, in Table 3 the average for each of the dimensions and other foundational elements of SLE-5 according to their level of appropriateness, ambiguity and importance is shown. It should be borne in mind that the names which appear in the table are not the definitive ones in the model.

Firstly, it is worth highlighting the soundness of all the dimensions, as the values of appropriateness and importance are equal or higher than 3.3. However, there are a number of lower values, while not lower than 2, associated with the ambiguity of the dimensions of smart education, (smart) assessment, (smart) technology and ergonomics layer. Echoing a more qualitative type of vision, the experts suggested different modifications. Basically, the changes can be summarized in: change of terms (the use of Smart or "enriched" in certain dimensions), the use of the concept "smart education" or "smart pedagogy" which have been substituted by "enriched methodologies and strategies"; some indicators have been integrated in other dimensions (especially those related to instructional design); some concepts have been specified with more precision (educational agents, roles or Smart technology, which should not be mistaken for artificial intelligence).

\section{Our proposal of a new model: SLE-5}

The model presented in this paper offers an approach to smart learning from an educational perspective, which can favor a transfer to the practice. In any SLE proposal, virtual and physical environments must be combined, so that educational agents and students can carry out their communicative, reflective, collaborative, in short, educational tasks in the most optimized way possible. Therefore, it has to consider the best methodological, evaluative, technological and space-temporal choices that best suit the students. Considering that an adaptable model is present at any educational level, the proportion of virtuality and presence of an SLE is modifiable according to the educational purposes.

Our model considers ergonomics as the main axis of the SLE, since it is the discipline that guarantees the physical and virtual adaptability of the educational action, both for accessing information and for the development of any activity. Specifically, in the representation of the model, ergonomics is involving both environments (face to face and virtual) to manage the space according to the implemented methodologies, to recognize the needs about adaptive or assistive technologies, offer learning alternatives, among other measures that favor the progress and well-being of any person involved (García-

Table 3 Expert judgment means

\begin{tabular}{|c|c|c|c|c|c|c|}
\hline & \multicolumn{6}{|c|}{ Dimensions proposed } \\
\hline & $\begin{array}{l}1 . \\
\text { Educational } \\
\text { curriculum }\end{array}$ & $\begin{array}{l}2 . \\
\text { Smart } \\
\text { Education }\end{array}$ & $\begin{array}{l}3 . \\
\text { (Smart) } \\
\text { Assessment }\end{array}$ & $\begin{array}{l}4 . \\
\text { Educational } \\
\text { Roles }\end{array}$ & $\begin{array}{l}5 . \\
\text { (Smart) } \\
\text { Technology } \\
\end{array}$ & Ergonomics \\
\hline Appropriateness & 3,8 & 3,3 & 3,5 & 3,8 & 3,8 & 3,3 \\
\hline Ambiguity & 3,8 & 2,8 & 3,1 & 3,5 & 3 & 2,8 \\
\hline Importance & 3,8 & 3,3 & 3,8 & 3,8 & 3,8 & 4 \\
\hline
\end{tabular}


Tudela et al., 2020). Next, Table 4 delves into each of the dimensions that should be considered to adapt an SLE proposal to any formal educational context.

In Fig. 5 we can see the graphic representation of this model. As can be observed, it features sequentiality, as when designing an SLE proposal, it is necessary to start making the appropriate decisions based on dimension 1. Once the last dimension has been attained, it is the moment of making the design a reality, evaluating the practical implementation, and starting a new design based on the second dimension, to suggest the optimal improvements.

The center of the graphic depicts the fusion of the two scenarios which articulate any SLE proposal, that is, technology enriched environment (face-to-face learning) and the virtual environment. Likewise, both are entrenched in a layer that considers ergonomics as an element which guarantees the adaptation, and optimization according to each necessity and learning style.

\section{Conclusions}

SLE also have a scientific impact in the field of computer science (Freigang et al., 2018) and that is why it is particularly interesting to address the concept from an exclusively

Table 4 Dimensions of the proposed SLE model

\begin{tabular}{|c|c|c|}
\hline Dimension & Definition & $\begin{array}{l}\text { Main source } \\
\text { reference }\end{array}$ \\
\hline Educational curriculum & $\begin{array}{l}\text { Starting point for each formal learning proposal is the coalescence } \\
\text { of the elements of the instructional design in the legislation and } \\
\text { official educational policies (competences, contents, standards ...) }\end{array}$ & Liu et al. (2017) \\
\hline $\begin{array}{l}\text { Enriched } \\
\text { methodologies and } \\
\text { strategies }\end{array}$ & $\begin{array}{l}\text { They are the fundamental pillars of technology-based instructional } \\
\text { designs and allows to connect the learning experience in physical } \\
\text { environments with the experience in virtual ones through an ad- } \\
\text { equate selection of educational methodologies and strategies } \\
\text { enriched with technology. }\end{array}$ & $\begin{array}{l}\text { Zhu, Yu, and } \\
\text { Riezebos (2016) } \\
\text { Liu et al. (2017) } \\
\text { Freigang et al., } \\
2018 \\
\text { Maulidiya et al. } \\
\text { (2019) } \\
\text { Yusufu and } \\
\text { Nathan (2020) }\end{array}$ \\
\hline Enriched assessment & $\begin{array}{l}\text { It entails the selection of the type of assessment (formative and/or } \\
\text { summative) and the strategies (hetero-evaluation, peer evaluation, } \\
\text { self-evaluation) which will be applied, as well as the techniques } \\
\text { (teacher's diary, questionnaires, rubrics, portfolios, etc.) always ana- } \\
\text { lyzing indicators from both learning environments mediated by } \\
\text { technologies (face-to-face and virtual). } \\
\text { Likewise, this dimension also considers the continuing monitoring } \\
\text { of students, mainly by means of learning analytics. }\end{array}$ & $\begin{array}{l}\text { Hwang (2014) } \\
\text { Maulidiya et al. } \\
\text { (2019) }\end{array}$ \\
\hline Educational roles & $\begin{array}{l}\text { There are certain main educational roles performed by students } \\
\text { and teachers, who carry out different duties, responsibilities, tasks, } \\
\text { levels of authority, etc., depending on decisions that have been } \\
\text { made in previous dimensions. } \\
\text { Besides, other educational roles are accordingly performed by } \\
\text { other education agents, as for instance mediation with families in } \\
\text { Primary or Secondary education, the support of the ICT } \\
\text { coordinator of the educational institution or social agents who } \\
\text { can contribute to the development of the experience. }\end{array}$ & $\begin{array}{l}\text { Hwang (2014) } \\
\text { Zhu, Sun, and } \\
\text { Riezebos (2016) } \\
\text { Zhu, Yu, and } \\
\text { Riezebos (2016) } \\
\text { Yusufu and } \\
\text { Nathan (2020) }\end{array}$ \\
\hline Smart technology & $\begin{array}{l}\text { The final decision when designing a SLE is the dimension related } \\
\text { to technology. Mainly smart hardware and software technologies } \\
\text { (electronic devices connected to Internet and digital applications } \\
\text { capable of automatizing functions) need to be integrated in these } \\
\text { environments, but also other technologies needed for the optimal } \\
\text { development of the educational proposal. Physical connectivity of } \\
\text { the classroom's technical features (Internet of Thing [loT]) and } \\
\text { automation need to be promoted. }\end{array}$ & $\begin{array}{l}\text { Hwang (2014) } \\
\text { Zhu, Sun, and } \\
\text { Riezebos (2016) } \\
\text { Laxmikant (2017) } \\
\text { Liu et al. (2017) } \\
\text { Shvetsova (2017) } \\
\text { Yusufu and } \\
\text { Nathan (2020) }\end{array}$ \\
\hline
\end{tabular}


educational perspective. In this work, following exhaustive basic research supported on the analysis of the state of the art and the experts' judgement, our own definition of SLE, and a model which enables its practical implementation are proposed. This way, we try to overcome the technological-pedagogical gap that SLE bring along, which is a rather recurrent problem in all of the proposals which aim to combine advanced technologies and innovative educational designs (Martínez-Sánchez, 2016; Prendes, Gutiérrez, \& Martínez, 2018).

As can be observed in the different SLE definitions and models, this possibility of integrating technology into educational reality could entail an imbalance between the technological and the educational, but SLE were not conceived to impair the educative process, but to optimize the learning experience. For this reason, it has been considered necessary to clarify concepts, design dimensions according to the scientific findings and the educational reality and sequence the design of a didactic proposal based on the SLE.

It is necessary to highlight that the use of smart technological devices or the implementation of a monitoring system does not mean that an SLE is being carried out. An

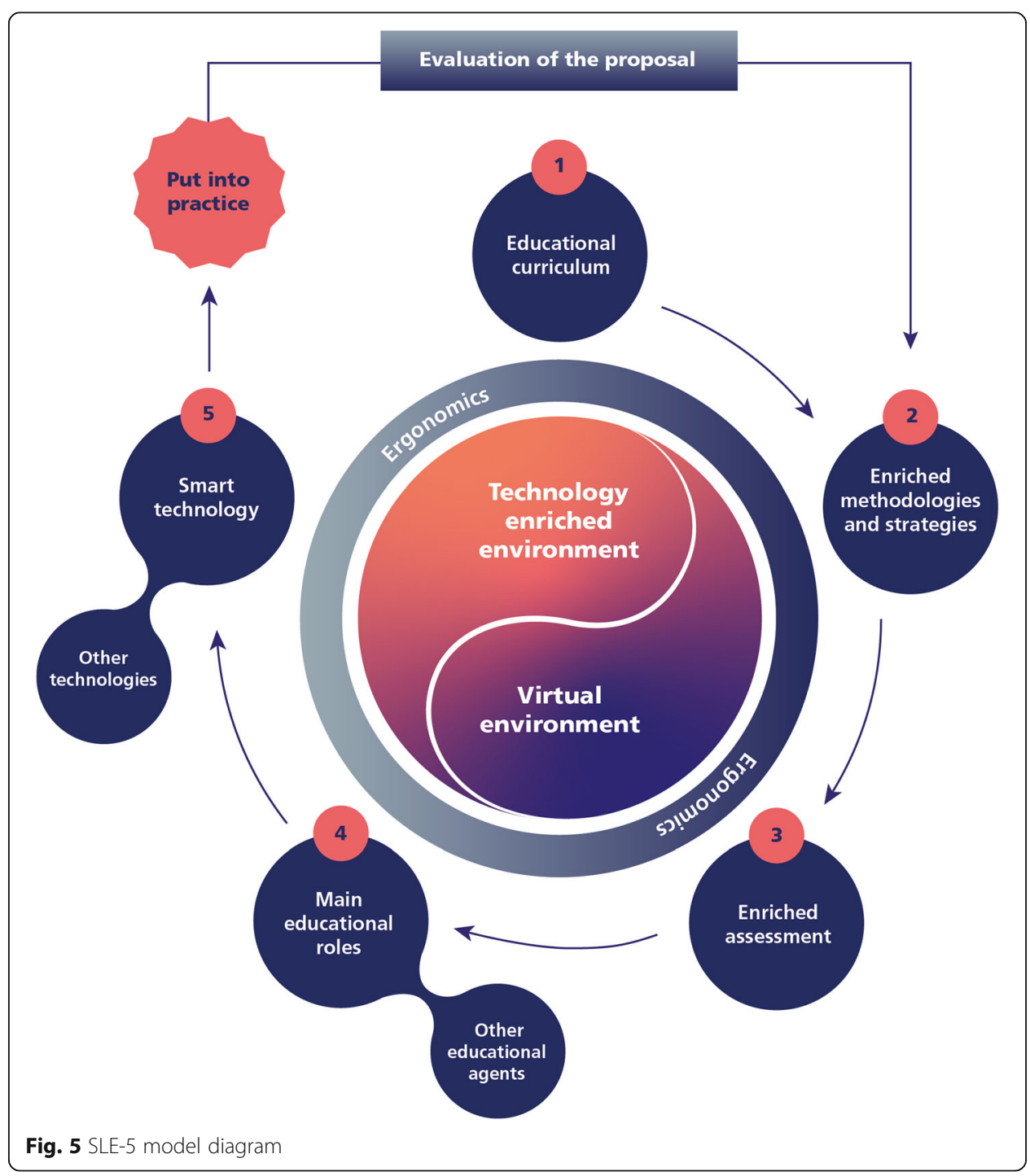


SLE implies the practical coalescence of different elements based on the five dimensions presented (educational curriculum, enriched methodologies and strategies, enriched assessment, educational roles and smart technology) and other fundamental aspects such as ergonomics and the presence of both environments (face-to-face and virtual) in a framework which promotes their symbiosis (physical environment enriched with technology and virtual environment).

In relation to the present work's limitations, one shared with $\mathrm{Zhu}, \mathrm{Yu}$, and Riezebos (2016) should be highlighted: those who suggest the need to characterize "smart pedagogy", that is, the necessity of defining exhaustively which are the methodologies and strategies inherent to an SLE. In this work this dimension (enriched methodologies and strategies) is generalized, as methodologies are not the ones which put the "smart" on the educational process, but instead every one of the decisions made in relation to the different dimensions. From this fact, it follows that an SLE can potentially make use of any educational methodology, so long as it is related to the rest of the elements of the proposal.

Finally, it is worth emphasizing that, on the one hand, this work represents a starting point for the practical transfer of SLE, at any level, even in Primary education, as the theorization of these environments is normally associated exclusively with higher education (Berdnikova et al., 2020; Gambo \& Shakir, 2019). Our proposed model (SLE-5) can be useful for both analysis of and reflection on the results shown as for design and implementation. And, on the other hand, through the results exposed we aim to promote new theoretical findings which complement the SLE- 5 and thus favor the progress of the subject of study from an educational perspective which minimizes the role of smart technologies, in favor of the so-called "smart education" a controversial concept on its own, in that it underlies the name itself, but which tries to emphasize the educational components of the experiences with SLE. Based on this model SLE-5, we will be able to develop further research to analyse the impact of these smart environments in learning outcomes of students from an educational approach. It is not relevant the technology itself, it is relevant the educational impact of these technologies in a connected classroom to promote student's learning. These innovative research will help us to understand the effects of the future education.

\section{Abbreviations}

SLE: Smart Learning Environments; ICT: Information and Communication Technology; loT: Internet of Things; BLearning: Blended Learning; M-Learning: Mobile Learning; U-Learning: Ubiquitous Learning; E-Learning: Electronic Learning; TEL: Technology Enriched Learning; PDA: Personal Digital Assistant

Acknowledgements

The authors are grateful to the team of experts who participated in this research.

\section{Authors' contributions}

Introduction, P.A.G.T, P.P.E and I.M.S.F; methodology, P.A.G.T, P.P.E and I.M.S.F; results, M.P.P.E, I.M.S.F and P.A.G.T; conclusions, P.A.G.T, P.P.E and I.M.S.F; writing, review and editing, P.A.G.T, P.P.E and I.M.S.F. Each author contributed equally to each part of this this paper. All authors read and approved the final manuscript. group in educational technology of the University of Murcia. Master in educational research and innovation. Degree in primary education with a mention in intercultural education and learning difficulties. His main research lines are about Smart Learning Environments, active learning methodologies (gamification, game based learning, etc.) and Eassessment. He is a member of some national and international research projects, such as GEM (Gender Equality Matters) or EmDigital (a digital entrepreneurship competence project). He has participated in some international conferences and has published in indexed journals about distance education and other mentioned topics. @Pe_xyz (Twitter). 
Paz Prendes-Espinosa is Full Professor in Educational Technology at the University of Murcia (Spain). Head of the Research Group in Educational Technology and Editor of RIITE, an online scientific journal about research in Educational Technology. Secretary of Edutec, international association to promote the development of Educational Technology. Coordinator of the PhD Programme in Educational Technology at the University of Murcia. Experience as Coordinator of Virtual Education and Coordinator of Educational Innovation in the same university. Currently, director of the research project EmDigital in relation to digital entrepreneurship in university degrees and AROSE, using digital tools to promote oral competences in English as secondary language. The main research topics are technology enhanced learning, e-learning, digital competence, Personal Learning Environment, Learning Management Systems and different uses of ICT as teaching-learning tools in all contexts -formal, no formal or informal-. @pazprendes (Twitter). Isabel María Solano Fernández is PhD by University of Murcia since 2004. She is Associate Professor in Educational Technology at the Department of Didactics and School Organization, Faculty of Education. Member of the Educational Technology Research Group (GITE) of the aforementioned University, as well as Edutec, international association to promote the development of Educational Technology. Her field of work is Educational Technology and she has been teaching related subjects in the Primary and Early Chilhood Education degrees for over 18 years. She has participated in different Erasmus+ and H2020 projects, as well as National research projects financed by the Ministry of Education or other institutions. Her research interests include the design, implementation and evaluation of technology in training contexts, audiovisual multimedia resources in formal and non-formal education, methodological strategies in primary and early childhood education, computational thinking and robotics and research methodology in educational technology. @imsolano (Twitter).

\section{Funding}

This work is part of a project to develop a model of smart learning environments and thus design didactic proposals to work gender equality in Primary Education. The Ministry of Science, Innovation and Universities (Spain) fund this project through the grant of the University Teacher Training Program (FPU18/02338).

\section{Availability of data and materials}

The authors have no conflict of interest to declare.

\section{Declarations}

\section{Competing interests}

The authors have no conflict of interest to declare.

Received: 20 January 2021 Accepted: 6 May 2021

Published online: 05 June 2021

\section{References}

Albino, V., Berardi, U., \& Dangelico, R. M. (2015). Smart cities: definitions, dimensions, performance, and initiatives. Journal of Urban Technology, 22(1), 3-21. https://doi.org/10.1080/10630732.2014.942092.

Bartolomé-Pina, A., García-Ruiz, R., \& Aguaded, I. (2018). Blended learning: panorama y perspectivas. RIED: Revista Iberoamericana de Educación a Distancia, 21(1), 33-56. https://doi.org/10.5944/ried.21.1.18842.

Bdiwi, R., de Runz, C., Faiz, S., \& Cherif, A. A. (2019). Smart learning environment: teacher's role in assessing classroom attention. Research in Learning Technology, 27. https://doi.org/10.25304/rlt.v27.2072.

Berdnikova, L. F., Mikhalenok, N. O., Pavlova, S. V., Gortcevskaia, O. G., \& Krivtsov, A. I. (2020). Intellectual resources in the development of smart university. Smart Innovation, Systems and Technologies, 188, 351-360. https://doi.org/10.1007/978981-15-5584-8_30.

Cárdenas-Robledo, L. A., \& Peña-Ayala, A. (2018). Ubiquitous learning: a systematic review. Telematics and Informatics, 35(5), 1097-1132. https://doi.org/10.1016/j.tele.2018.01.009.

Castañeda, L. J., Gutiérrez, I., Prendes, M. P., \& Sánchez, M. M. (2017). Formación docente para la enseñanza en línea en el contexto de la Formación Profesional. Universitas Tarraconencsis: Revista de Ciènces de l'Educació, 2, 29-44 Retrieved from https://bit.ly/39rv4QN.

Coccoli, M., Guercio, A., Maresca, P., \& Stanganelli, L. (2014). Smarter universities: a visión for the fast changing digital era. Journal of Visual Languages and Computing, 25(6), 1003-1011. https://doi.org/10.1016/j.jvlc.2014.09.007.

Ferri, F., D'Andrea, A., Grifoni, P., \& Guzzo, T. (2018). Distant learning: open challenges and evolution. International Journal of Learning, Teaching and Educational Research, 17(8), 78-88. https://doi.org/10.26803/ijter.17.8.5.

Freigang, S., Schlenker, L., \& Köhler, T. (2018). A conceptual framework for designing smart learning environments. Smart Learning Environments, 5(1), 27. https://doi.org/10.1186/s40561-018-0076-8.

Gambo, Y., \& Shakir, M. Z. (2019). New development and evaluation model for self-regulated smart learning environment in higher education. In A. K. Ashmawy, \& S. Schreiter (Eds.), IEEE Global Engineering Education Conference, (pp. 990-994). New York: IEEE. https://doi.org/10.1109/educon.2019.8725268.

García-Tudela, P. A., Prendes-Espinosa, M. P., \& Solano-Fernández, I. M. (2020). Smart learning environments and ergonomics: an approach to the state of the question. NAER: Journal of New Approaches in Educational Research, 9(2), 245-258. https:// doi.org/10.7821/naer.2020.7.562.

Gikas, J., \& Grant, M. M. (2013). Mobile computing devices in higher education: student perspectives on learning with cellphones, smartphones \& social media. The Internet and Higher Education, 19, 18-26. https://doi.org/10.1016/j.iheduc.2 013.06.002.

Giovannella, C. (2014). Smart learning eco-systems: "fashion" or "beef"? Journal of E-Learning and Knowledge Society, 10(3). https://doi.org/10.20368/1971-8829/971

Govender, D., \& Dhurup, M. (2014). Perceptions of learners of a learning management system to support teaching and learning using the difussion of innovation theory. Mediterranean Journal of Social Sciences Publishing, 5(8), 377-385 Retrieved from https://bit.ly/32zd45S. 
Graham, C. R. (2006). Blended learning systems: definition, current trends, and future directions. In C. J. Bonk, \& C. R. Graham (Eds.), Handbook of blended learning: global perspectives, local designs, (pp. 3-21). San Francisco: Pfeiffer Publishing Retrieved from https://bit.ly/2YyEBTD.

Graham, C.R., Henrie, C. \& Gibbons, A. (2013). Developing models and theory for blended learning research. In A. Picciano, C. Dziuban y C. Graham (Eds.), Research perspectives in blended learning: research perspectives (pp. 13-33). London: Routledge. Retrieved from https://bit.ly/2EyynMr

Harris, J., \& Hofer, M. (2009). Instructional planning activity types as vehicles for curriculum-based TPACK development. In C. D. Maddux (Ed.), Research highlights in technology and teacher education 2009, (pp. 99-108). Asheville: Society for Information Technology in Teacher Education Retrieved from https://bit.ly/3bGVnWe.

Hasanov, A., \& Laine, T. H. (2017). A survey of context-awareness in learning environments in 2010-2016. In P. Escudeiro, G. Costagliola, S. Zvacek, J. Uhomoibhi, \& B. M. McLaren (Eds.), Proceedings of the 9th International Conference on Computer Supported Education - volume 1, (pp. 234-241). Portugal: Scitepress. https://doi.org/10.5220/0006255302340241.

Heinemann, C., \& Uskov, V. L. (2018). Smart University: iterature review and creative analysis. In V. Uskov, J. Bakken, \& J. L. Howlett (Eds.), Smart innovation, system and technologies, (pp. 11-46). Cham: Springer. https://doi.org/10.1007/978-3-31959454-5_2.

Hernández, R., Fernández, C., \& Baptista, P. (1991). Metodología de la Investigación (5. a Edición). Mexico: McGraw-Hill.

Huh, K., \& Lee, J. (2019). Fostering creativity and language skills of foreign language learners through SMART learning environments: evidence from fifth-grade Korean EFL learners. TESOL Journal, 11(2). https://doi.org/10.1002/tesj.489.

Hwang, G. J. (2014). Definition, framework and research issues of smart learning environments -a context- aware ubiquitous learning perspective. Smart Learning Environments, 1, 4. https://doi.org/10.1186/s40561-014-0004-5.

Hwang, G. J., \& Tsai, C. C. (2011). Research trends in mobile and ubiquitous learning: a review of publications in selected journals from 2001 to 2010. British Journal of Educational Technology, 42(4), E65-E70. https://doi.org/10.1111/j.1467-8535.2 011.01183.x.

Katoningish, S., Wardhani, J. D., \& Fauziah \& Astuti, W. (2020). Mobile learning as a media training of reading literacy: blended learning. Journal of Physics: Conference Series, 1511(1), 012021. https://doi.org/10.1088/1742-6596/1511/1/012021.

Khlaif, Z. N., \& Farid, S. (2018). Transforming learning for the smart learning paradigm: lessons learned from the Palestinian initiative. Smart Learning Environments, 5, 12. https://doi.org/10.1186/s40561-018-0059-9.

Kim, K. J., Bonk, C. J., \& Oh, E. (2008). The present and future state of blended learning in workplace learning settings in the United States. Performance Improvement, 47(8). https://doi.org/10.1002/pfi.20018.

Kim, T., Cho, J. Y., \& Lee, B. G. (2013). Evolution to smart learning in public education: a case study of Korean Public Education. In T. Ley, M. Ruohonen, M. Laanpere, \& A. Tatnall (Eds.), Open an social technologies for networked learning, (pp. 170-178). Berlin: Springer. https://doi.org/10.1007/978-3-642-37285-8_18.

Kinshuk, Chen, N. S., Cheng, I. L., \& Chew, S. W. (2016). Evolution is not enough: revolutionizing current learning environments to smart learning environments. International Journal of Artificial Intelligence in Education, 26, 561-581. https://doi.org/10.1 007/s40593-016-0108-X.

Koehler, M. J., \& Mishra, P. (2009). What is technological pedagogical content knowledge? Contemporary Issues in Technology and Teacher Education, 9(1), 60-70 Retrieved from https://bit.ly/35c745Y.

Koper, R. (2014). Conditions for effective smart learning environments. Smart Learning Environments, 1(1). https://doi.org/10.11 86/s40561-014-0005-4.

Kurt, S. (2014). Creating technology-enriched classrooms: implementational challenges in Turkish education. Learning, Media and Technology, 39(1), 90-106. https://doi.org/10.1080/17439884.2013.776077.

Laxmikant, S. (2017). Smart education service model based on loT technology. International Interdesciplinar Conference on Science Technology Engineering Management Pharmacy and Humanities Held https://bit.ly/3iygFRH.

Lazar, S., \& Milena, B. (2013). M-Learning: a new form of learning and education. International Journal of Cognitive Research in Science, Engineering and Education, 1(2), 114-118 https://bit.ly/2DygOfu.

Lei, C. U., Wan, K., \& Man, K. L. (2013). Developing a smart learning environment in universities via cyber-physical systems. Procedia Computer Science, 17, 583-585. https://doi.org/10.1016/j.procs.2013.05.075.

Li, B., Kong, S. C., \& Chen, G. (2015). Development and validation of the smart classroom inventory. Smart Learning Environments, 2(1). https://doi.org/10.1186/s40561-015-0012-0.

Liu, D., Huang, R., \& Wosinski, M. (2017). Characteristics and framwork of smart learning. In L. Dejian, H. Ronghuai, \& W. Marek (Eds.), Smart learning in smart cities, (pp. 31-48). Singapore: Springer. https://doi.org/10.1007/978-981-10-4343-7_3.

Luna-Gijón, G., \& Porras-Hernández, L. H. (2014). Validación de un modelo instrucción centrado en el diseño de materiales digitales de aprendizaje. Investigación en Educación Médica, 3(11), 123-130. https://doi.org/10.1016/S2007-5057(14)72738-3.

Martínez-Sánchez, F. (2016). Sentado en el andén. RIITE: Revista Interuniversitaria de Investigación en Tecnología Educativa, 0 , 17-22. https://doi.org/10.6018/riite/2016/258131.

Maulidiya, D., Santoso, H.B. \& Hasibuan, Z.A. (2019). A conceptual multi-dimensional model for smart learning environments. In 2019 International Conference on Advanced Computer Science and Information Systems (ICACSIS). doi: https://doi.org/1 $0.1109 /$ icacsis47736.2019.8979679.

Montebello, M. (2017). Smart Ubiquitous learning environments. International Journal of Education, 5(4), 17-24. https://doi. org/10.5121/ije.2017.5402.

Prendes, M. P. (2018). La Tecnología Educativa en la Pedagogía del siglo XXI: una visión en 3D. RIITE: Revista Interuniversitaria de Investigación en Tecnología Educativa, 4, 6-16. https://doi.org/10.6018/riite/2018/335131.

Prendes, M.P., Gutiérrez, I. y Martínez, F. (2018). Competencia digital: una necesidad del profesorado universitario en el siglo XXI. RED: Revista de Educación a Distancia, 56: 7. doi: https://doi.org/10.6018/red/56/7

Reguant-Álvarez, M. y Torrado-Fonseca, M. (2016). El método Delphi. REIRE: Revista d'Innovació i Recerca en Educació, 9(1), 87102. doi: http://bit.ly/2lxj3P6

Roblek, V., \& Meško, M. (2020). Smart city knowledge management: holistic review and the analysis of the urban knowledge management. In S. J. Eom, \& J. Lee (Eds.), The 21st Annual International Conference on Digital Government Research, (pp. 52-60). New York: Association for Computing Machinery Retrieved from https://bit.ly/31PiudC.

Sabariego, M., Massot, I. \& Dorio, I. (2004). Métodos de investigación cualitativa. En R. Bisquerra (Ed.), Metodología de la

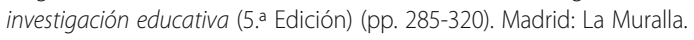


Salinas, J. (2012). La investigación ante los desafíos de los escenarios de aprendizaje futuros. RED: Revista de Educación a Distancia, 32. https://doi.org/10.6018/red/50/13.

Salinas, J., De Benito, B., Pérez, A., \& Gisbert, M. (2018). Blended Learning, más allá de la clase presencial. RIED: Revista Iberoamericana de Educación a Distancia, 21(1), 195-213. https://doi.org/10.5944/ried.21.1.18859.

Sarrab, M. (2019). Distance, virtual, electronic, mobile and ubiquitous learning environments: taxonomy study. In ICIET (Ed.), Proceedings of the 2019 7th international conference on information and education technology, (pp. 36-43). Association for Computing Machinery. https://doi.org/10.1145/3323771.3323813.

Semenova, N. V., Svyatkina, E. A., Pismak, T. G., \& Polzhaeva, Z. Y. (2017). The realities of smart education in the contemporary Russian universties. In D. Trutnev (Ed.), Proceedings of the international conference on electronic governance and open society: challenges in Eurasia, (pp. 48-52). New York: Association for computing Machinery. https://doi.org/10.1145/312 9757.3129767.

Shvetsova, O. A. (2017). Smart education in high school: new perspectives in global world. In 2017 International conference "quality management, transport and information security, information technologies" (IT\&QM\&IS). New York: IEEE. https://doi. org/10.1109/itmqis.2017.8085917.

Siripongdee, K., Pimdee, P., \& Tuntiwongwanich, S. (2020). A blended learning model with loT-based technology: effectively used when the COVID-19 pandemic? Journal for the Education of Gifted Young Scientist, 8(2), 905-917. https://doi.org/10.1 7478/jegys.698869.

Spector, J. M. (2014). Conceptualizing the emerging field of smart learning environments. Smart Learning Environments, 1(1), 2. https://doi.org/10.1186/s40561-014-0002-7.

Tikhomirov, V., Dneprovskaya, N., \& Yankovskaya, E. (2015). Three dimensions of smart education. Smart Education and Smart e-Learning, 47-56. https://doi.org/10.1007/978-3-319-19875-0_5.

Virtanen, M. A., Haavisto, E., Liikanen, E., \& Kääriäinen, M. (2018). Ubiquitous learning environments in higher education: a scoping literature review. Education and Information Technologies, 23, 985-998. https://doi.org/10.1007/s10639-017-9646-

Wakil, K., Qaisar, N., \& Mohammed, C. (2017). Enriching classrooms with technology in the basic schools. European journal of Open Education and E-Learning Studies, 2(1), 99-108 Retrieved from https://bit.ly/337ffxL.

Whalley, B., France, D., Park, J., Mauchline, A., \& Welsh, K. (2020). Developing active personal learning environments on smart mobile devices. Adv. Intell. Syst. Comput., 1070, 871-889. https://doi.org/10.1007/978-3-030-32523-7_64.

Winters, N. (2007). What is mobile learning? In M. Sharples (Ed.), Big issues in mobile learning, (pp. 4-8). England: University of Nottingham Retrieved from https://bit.ly/3gWkOnq.

Yeh, Y. F., Hsu, Y. S., Wu, H. K., Hwang, F. K., \& Lin, T. C. (2013). Developing and validating technological pedagogical content knowledge-practical (TPACK-practical) through the Delphi survey technique. British Journal of Educational Technology, 45(4). https://doi.org/10.1111/bjet.12078.

Yusufu, G., \& Nathan, N. (2020). A novel model of smart education for the development of smart university system. In 2020 International Conference in Mathematics, Computer Engineering and Computer Science. New York: IEEE. https://doi.org/10.11 09/icmcecs47690.2020.240912.

Zhu, Z., Sun, Y., \& Riezebos, P. (2016). Introducing the smart education framework: core elements for successful learning in a digital world. International Journal of Smart Technology and Learning, 1(1), 53. https://doi.org/10.1504/ijsmarttl.2016.0781 59.

Zhu, Z., Yu, M. H., \& Riezebos, P. (2016). A research framework of smart education. Smart Learning Environments, 3(1). https:// doi.org/10.1186/s40561-016-0026-2.

\section{Publisher's Note}

Springer Nature remains neutral with regard to jurisdictional claims in published maps and institutional affiliations.

\section{Submit your manuscript to a SpringerOpen ${ }^{\circ}$ journal and benefit from:}

- Convenient online submission

- Rigorous peer review

- Open access: articles freely available online

- High visibility within the field

- Retaining the copyright to your article

Submit your next manuscript at $\boldsymbol{\nabla}$ springeropen.com 